\title{
Nino Latsabidze
}

\section{Constitutional Control in Georgia and the Right to Consider and Adjudicate upon the Constitutionality of the Decisions of Common (Ordinary) Courts}

\section{ABSTRACT}

This article deals with the specialised organ of constitutional review - the Constitutional Court of Georgia and analyses the possibility of granting the Constitutional Court the right to consider and adjudicate upon the decisions of common (ordinary) courts. The Constitutional Court mainly carries out repressive and abstract control. In general, it considers the constitutionality of normative acts. Most of the constitutional claims apply to compliance of the normative acts with the second chapter of the Constitution of Georgia, which guarantees basic rights and the freedom of individuals. Recently, the Public Defender of Georgia launched an initiative to add to the power of the Constitutional Court to consider the constitutionality of the decisions of the courts of last resort. Granting the Constitutional Court this authority is associated with many positive factors. First of all, the Constitutional Court will become the court of last resort in terms of the European Convention on Human Rights and thus, the number of applications against Georgia will be reduced. It will require less financial resources than in case of making application to the European Court of Human rights and the final decision will be adopted in shorter terms. Consequently, the new authority of the Constitutional Court can become a more effective human rights protection mechanism. The new authority may interfere with the common court's competence; however, finally, the initiative should be positively evaluated.

Keywords: Constitutional Court of Georgia, Public Defender of Georgia, constitutional control 


\section{Nino Latsabidze}

\section{Kontrola konstytucyjności w Gruzji a prawo rozpoznawania i orzekania o konstytucyjności orzeczeń sądów powszechnych}

\section{STRESZCZENIE}

Przedmiotem artykułu jest analiza kompetencji gruzińskiego Trybunału Konstytucyjnego do badania konstytucyjności orzecznictwa sądów powszechnych. Trybunał Konstytucyjny dokonuje kontroli głównie następczej i abstrakcyjnej, przede wszystkim rozstrzyga o konstytucyjności aktów normatywnych. W większości przypadków dotyczy to zgodności aktów normatywnych z drugim rozdziałem Konstytucji Gruzji, gwarantującym podstawowe prawa i wolności jednostki. Ostatnio Obrońca Publiczny (odpowiednik Rzecznika Praw Obywatelskich) wystąpił z inicjatywą upoważnienia Trybunału Konstytucyjnego do badania konstytucyjności orzeczeń sądów ostatniej instancji. Na korzyść takiego upoważnienia przemawia wiele czynników. Przede wszystkim Trybunał Konstytucyjny stanie się sądem ostatniej instancji w rozumieniu Europejskiej Konwencji Praw Człowieka, co pociągnie za sobą zmniejszenie liczby wniosków przeciwko Gruzji. Wymagać to będzie mniejszych nakładów finansowych niż w przypadku składania wniosków do Europejskiego Trybunału Praw Człowieka, a ostateczne decyzje zostaną szybciej podjęte. W związku z tym nowe uprawnienie Trybunału Konstytucyjnego może stanowić bardziej skuteczny mechanizm ochrony praw człowieka. Jakkolwiek nowe uprawnienie Trybunału pozwala na ingerencję $\mathrm{w}$ kompetencje sądu powszechnego, to generalnie inicjatywa rzecznika powinna być oceniona pozytywnie.

Słowa kluczowe: Trybunał Konstytucyjny Gruzji, Obrońca Publiczny, kontrola konstytucyjności 


\section{THE HISTORY OF THE CONSTITUTIONAL COURT OF GEORGIA}

Special organ exercising the powers of constitutional control, Constitutional Court of Georgia was established in 1996 on the basis of the Constitution of Georgia adopted in 1995. The majority of the authors of the constitution refused diffuse (i.e. dispersed) system of constitutional review, in which all courts of common jurisdiction, review the constitutionality of the statutes and administrative measures in specific proceedings using common procedural rules. They did not support the idea to establish constitutional board within the Supreme Court of Georgia and voted for concentrated model of constitutional control. In such a system the exclusive power of constitutional control is reserved for the specialized constitutional organ - the constitutional court. ${ }^{1}$

The legal basis of the organisation and activity of the Constitutional Court of Georgia is the Constitution of Georgia, the Organic Law of Georgia "On the Constitutional Court of Georgia", the Law of Georgia "On the Constitutional Legal Proceedings" and the Rules of the Constitutional Court.

The Constitutional Court of Georgia has moved from Tbilisi to Batumi in 2007, July 5 .

\section{The organization and formation rules of the Constitutional Court of Georgia}

Constitutional Court of Georgia exercises not justice, but constitutional control. Hence, some of the constitutional law experts consider that constitutional court is separated from judicial system. However, paragraph 1 of the article 82 of the Constitution of Georgia states that: "Judicial power shall be exercised by means of constitutional control, justice and other forms determined by law."

Constitutional Court of Georgia consists of nine members. In the process of formation of Constitutional Court all of the three branches take part equally, as three members of court are appointed by the President of Georgia, three

1 A. Demetrashvili, Constitutional Law Manual, Tbilisi, 2005, p. 335. 
members are elected by the parliament not less than three fifths of the number of the members of the Parliament on the current nominal list and three members are appointed by the Supreme Court of Georgia.

Eligibility requirements for the post of the member of Constitutional Court are not precisely defined unlike the eligibility criteria for the judges of common (ordinary) courts. Article 88 of the Constitution of Georgia establishes: "A member of the Constitutional Court may be a citizen of Georgia who has attained the age of 30 and has the highest legal education." Article 7 of the organic law of Georgia "on the Constitutional Court of Georgia" determines additional selection criteria for the members of Constitutional Court, in particular: "When deciding on the members of the Constitutional Court of Georgia, the President of Georgia, the Parliament of Georgia and the Supreme Court of Georgia should take into account the professional experience of a candidate, which should be appropriate for the high status of a member of the Constitutional Court". The eligibility criteria established for the members of Constitutional Court have been subjected to severe criticism for several times. Professor O. Melkadze mentioned that: "the latter formula focuses on the essential term for the selection in a not strictly obligatory form, because the very act of taking into account 'the professional experience of a candidate should correspond to the high status of the member of the Constitutional Court' does not contain the terminology defining a sense of 'selection' at all." ${ }^{2}$

The term of the office of the Constitutional Court is ten years.

\section{Authority of the Constitutional Court of Georgia}

Constitutional Court of Georgia mainly carries out repressive and abstract constitutional control. The only case of preventive control is when Constitutional Court of Georgia examines the constitutionality of the international agreements that need the ratification exercised by the parliament. Constitutional Court also carries out formal constitutional control, when it is authorized to consider and adjudicate upon conformity with the Constitution of Georgia of a constitutional agreement, laws of Georgia, normative resolutions of the Parliament of Georgia, normative acts of the President of Georgia,

2 0. Melkadze, Some Aspects Regarding the Constitutionality of the Organic Law of Georgia on the Constitutional Court, "Journal Georgian Law Review", $10^{\text {th }}$ edition, 2001, p. 59.

http://media.wix.com/ugd/1ee20c_426a5dfdb6344548ae021a7085988b78.pdf 
the Government of Georgia and those of the higher state bodies of the Autonomous Republics of Abkhazia and Ajara as well as conformity of adoption/ enactment, signing, promulgation and entry into force of legislative acts of Georgia and resolutions of the Parliament of Georgia with the Constitution of Georgia.

In general Constitutional Court of Georgia considers the constitutionality of the normative acts. According to the paragraph 3 of article 2 of the law of Georgia "On Normative Acts", normative act is: "a legal act, adopted (issued) by an authorized state body (official) or a body (an official) of local self-government (government) in accordance with the rule defined by the legislation, that prescribes a general rule for permanent or temporary and recurrent application of this act." The exceptional case, when constitutional court examines constitutionality of an individual legal act (An individual legal act is valid for one occasion only, and it shall conform to a normative act. The individual legal act shall be adopted (issued) only on the grounds of the normative act and within the limits prescribed by the latter ${ }^{3}$ ) is when Court examines constitutionality of recognition or pre-term termination of the authority of a member of the Parliament of Georgia.

Apart from the abovementioned issues, Constitutional Court of Georgia is authorized to consider and adjudicate upon: dispute on competence between state bodies; constitutionality of formation and activity of political associations of citizens; dispute on constitutionality of referendum or elections. Competence of the Constitutional Court in relation to the resolution of the issues of the constitutionality of the elections and referendums after the amendments in 2005 was formulated as follows: The Constitutional Court is authorized to examine the constitutionality of elections and referendums only together with the issue of the constitutionality of the norms that regulate these activities ${ }^{4}$. Prior to this constitutional amendment, the objective of the Constitutional Court was to establish (of course, in the case an application was made by a relevant subject) whether the requirements of the basic law of the country were being complied with while the institutions of the referendum and the election were in $u^{5}{ }^{5}$. Competence of the court also

3 The law of Georgia “On Normative Acts", paragraph 4 of article 2.

4 J. Khetsuriani, The Authority of the Constitutional Court of Georgia, Issues of the Constitutionality of referendum and Elections, "Constitutional Law Review" 2009, no. 1, p. 49.

5 J. Khetsuriani, The Authority of the Constitutional Court of Georgia, Issues of the Constitutionality of referendum and Elections, "Constitutional Law Review" 2009, no. 1, p. 48. 
includes adjudicating upon the constitutionality of international treaties and agreements; violation of the Constitution of Georgia by the President of Georgia, the President of the Supreme Court of Georgia, a member of the Government of Georgia, the President of the Chamber of Control of Georgia and the members of the Council of the National Bank of Georgia; dispute on violation of the constitutional law of Georgia on the Status of the Autonomous Republic of Ajara; conformity of normative acts of the Supreme Council of the Autonomous Republic of Ajara with the Constitution of Georgia, the constitutional law of Georgia on the Status of the Autonomous Republic of Ajara, the constitutional agreement, international treaties and agreements of Georgia and laws of Georgia. In addition to that, if, while considering a particular case, a court of general jurisdiction concludes, that there is a sufficient ground to deem the law or other normative act, applicable by the court while adjudicating upon the case, fully or partially incompatible with the Constitution, the court shall suspend the consideration of the case and apply to the Constitutional Court. The consideration of the case shall be resumed after a judgment on the issue is adopted by the Constitutional Court. ${ }^{6}$

Constitutional Court also examines constitutionality of the normative acts adopted in terms of chapter two of the Constitution of Georgia. Chapter two of the Constitution of Georgia guarantees the basic rights and freedoms of individual. Most of the constitutional claims apply to compliance of the normative acts with the second chapter of the Constitution of Georgia.

The definition of the Constitutional Court's decision clearly outlines that a normative act to be considered by the court must be adopted not generally in relation to human rights, but in relation to "fundamental human rights and freedoms". At the same time these "fundamental rights and freedoms" must be recognized under Chapter II of the Constitution. ${ }^{7}$ However, article 39 of the Constitution states that: "Georgian Constitution shall not deny other universally recognized rights, freedoms and guarantees of an individual and a citizen, which are not referred to herein, but stem inherently from the principles of the Constitution". Therefore, if a normative act, which are not provided the Constitutional Court may consider the disputed normative act's constitutionality only if it's substantiates that the right in question

6 The organic law of Georgia "on the Constitutional Court of Georgia", article 19.

7 J. Khetsuriani, The Georgian Constitutional Court 's Power in the Protection of Fundamental Human Rights, “Constitutional Law Review" 2011, no. 4, p. 48. 
"stems inherently from the principles of the Constitution" and belongs to the category of fundamental rights and freedoms. ${ }^{8}$

In order to determine whether this or that human right, which is not provided in the Constitution, belongs to the category of fundamental rights, the Constitutional Court shall prove that the right in question is an inalienable human right and is inherent to any person, that the state cannot deprive a person of this right or deny its recognition, and that it stems inherently from the principles of democracy, legal state, social state, division of powers and other principles enshrined in the Constitution. ${ }^{9}$

Every natural and legal person, who believes that disputed act or the part of it violates or can violate any fundamental right or freedom granted by the constitution, is entitled the right to submit a constitutional claim. Claimant shall provide evidence to the Court proving the fact of an intrusion of rights. ${ }^{10}$ It follows from paragraph 1 of article 42 of the Constitution of Georgia, which states that: "Everyone has the right to apply to a court for the protection of his/her rights and freedoms." This provision eliminates the so-called actio popularis and i absracto (abstract) claims ${ }^{11}$. Only the Public Defender of Georgia is authorized to lodge a constitutional claim in order to protect the rights and freedoms of the other person (so-called abstract control). The Public Defender is obliged to explain how a disputable normative act conflicts with the human rights and freedoms recognized under Chapter II of the Constitution, although he or she is not required to present concrete facts of human rights violations by a disputable normative act to prove the above said. ${ }^{12}$

8 J. Khetsuriani, The Georgian Constitutional Court's Power in the Protection of Fundamental Human Rights, “Constitutional Law Review" 2011, no. 4, p. 51.

9 Levan Izoria, Konstantine Korkelia, Konstantine Kublashvili, Giorgi Khubua. Comments on the Georgian Constitution. Fundamental Human Rights and Freedoms. Meridiani publishing house, Tbilisi, 2005, pp. 334-336.

${ }^{10}$ Georgian Citizens - Aleksandre Baramidze, Irakli Kandashvili and commandite society Andronikashvili, Saxen-Altenburgh, Baramidze and Partners vs Georgian Parliament, Decision No. 1/1/43 of the First Board of the Constitutional Court, Tbilisi, 1 March 2007.

11 T. Tugushi, G. Burjanadze, G. Mshvenieradze, G. Gotsiridze and V. Menabde, Human Rights and Case-Law of the Constitutional Court of Georgia, Tbilisi, 2013, p. 608.

12 J. Khetsuriani, The Georgian Constitutional Court's Power in the Protection of Fundamental Human Rights, “Constitutional Law Review" 2011, no. 4, p. 60. 


\section{RIGHT TO CONSIDER AND ADJUDICATE UPON THE CONSTITUTIONALITY OF THE DECISIONS OF COMMON COURTS}

Recently, Public Defender of Georgia launched a new initiative and proposed to make amendments to the provision regulating authorities of the Constitutional Court of Georgia, namely to add the power to consider constitutionality of the decisions of the common courts of last resort. More specifically, according to this initiative the Constitutional Court should gain the right to examine whether the incorrect interpretation of particular legal norm by the common court violates the fundamental rights and freedoms guaranteed by the Constitution of Georgia.

Interpretation of the norms on the basis of which common courts make final decisions, is directly connected to the principle of foreseeability. "The principle of foreseeability does not have normative content in the text of the constitution; however Constitutional Court reads the obligation to assess constitutionality of the norm based on this criterion out of the essence of the principle of the Rule of Law based state. The Constitutional Court repeatedly emphasized importance of the principle of Rule of Law based state the certain elements of which are expressed in lots of constitutional provisions. Apart from that, there are the elements of the Rule of Law based state which might not be considered by some of the constitutional norms, but still they can be granted no less importance as without them it is impossible to implement the principle of Rule of Law based state. Such element of the principle of Rule of Law based state is so-called "principle of foreseeability".

Unclearness and vagueness of the disputed norms may mislead participants of the legal relation and increase the risk of violating human rights, because, on the one hand, it may mislead the addressee of the norm about the legal circumstances caused by this norm, on the second hand, it can grant the judge the ground to act arbitrarily, to interfere excessively with the human rights. Therefore, the Constitutional Court saw its' obligation to determine while assessing and analyzing constitutionality of the norm whether the uncertainty of the law caused the violation of the right. Accordingly, Constitutional Court presented criterion to assess the "quality of the law" 13 .

${ }^{13} \mathrm{~K}$. Eremadze, The balancing of interests in a democratic society, 2013, p. 132. 
Given the fact that Constitutional Court examines compliance of the norms with the second chapter of the Constitution, the issue of compatibility of the law or the part of it with the principle of foreseeability cannot be raised separately. Members of the Constitutional Court have different approaches regarding the issue when the claimant is able to dispute about the foreseeability of the norm. The question can be raised in two ways. Norm does not satisfy the requirement of the principle of foreseeability, on the one hand, if it gives the possibility to interpret it unconstitutionally; or on the other hand, only in case when none of the interpretations of the norm comply with the Constitution.

Constitutional Court in its decision of $13^{\text {th }}$ of May, 2009, stated that: "because the norm may permit various interpretations and contribute to the existence of different precedents, does not mean that the norm is unconstitutional. In a result exactly the various interpretations become the ground for determining the right interpretation. There are enough mechanisms even in the terms of positive law, to determine which precedent should be considered as a right one. Judicial authorities are obliged to interpret the norm in compliance with the Constitution, if it is possible within the bounds of the norm. Not only must the normative acts be in compliance with the constitution, but their interpretations as well. If normative act provides a reasonable ground for reading with the content contradicting with the constitution, it fails to comply with requirements of foreseeability and shall be recognized as unconstitutional. And in the case when normative act also can be interpreted in compliance with the constitution, interpretations of the normative act become the subject for assessment. Possibility of different interpretation of the norm makes it doubtful. When the norm is doubtful the presumption of constitutionality of the norm operates and therefore it should be interpreted in compliance with the constitution."14

However, one of the members of the Constitutional Court did not agree with this approach and set out her arguments in dissenting opinion: "Ambiguity of the norm forms the basis for interpreting the norm in a various ways by different judges. Of course, if the judge believes that constitutionality of the norm is doubtful he/she must act in conformity with the constitution. But this does not solve the problem of the constitutionality of the norm. There is no doubt that judge has the duty to act in accordance with the

${ }^{14}$ Decisions of Constitutional Court of Georgia with short commentaries - Besik Loladze, Batumi, 2010, p. 200. 
constitution, violation of which leads to corresponding consequences, but existence of such obligation does not nullify unconstitutionality of the norm and it cannot justify leaving the unconstitutional norms in force." 15

In the same decision Constitutional Court also mentioned that while assessing normative acts Constitutional Court takes into consideration existing precedents, but constitutionality of the norm should be based on its' content and not only on the law enforcement practice. ${ }^{16}$

In one of the recent cases of the court we can notice that this practice tend to change. More specifically, court did not interpret impugned norm separately and did not assess whether the norm formed the basis for defining it in conformity with the constitution, but used the interpretation of the norm according to which common court judges made a final decision. In its' decision Constitutional Court states that examining the lawfulness of the decisions of common courts is beyond the authority of the Constitutional Court and thus, court delivered a rule on admissibility taking into consideration the content of the norm determined by common courts. ${ }^{17}$

If Constitutional Court will share the recent practice in its decisions and consider the content of the norms determined by the common courts, there may be no longer the need to add a new authority to existing ones. If the person believes that the court interpreted the norm unconstitutionally, what resulted in the violation of the fundamental rights or freedoms guaranteed by the constitution, he/she will lodge a claim demanding to declare the norm as unconstitutional. In that case court will consider the content of the norm determined by the common court.

Apart from that the judge of the common court is obliged to obey the constitution and thus, define the norm in compliance with it. If while considering the case, the judge concludes that there is a sufficient ground to deem the law or the part of it fully or partially incompatible with the constitution, he/she should suspend consideration of the case and apply to the Constitutional Court.

\footnotetext{
${ }^{15}$ Decisions of Constitutional Court of Georgia with short commentaries - Besik Loladze, Batumi, 2010, p. 208.

${ }^{16}$ Decisions of Constitutional Court of Georgia with short commentaries - Besik Loladze, Batumi, 2010, p. 200.

17 Decision of the Constitutional Court of Georgia N3/2/574 "the citizen of Georgia Giorgi Ugulava v. the Parliament of Georgia"; pp. 35-36.
} 
However, it should be noted that decision of the Constitutional Court of Georgia is a newly revealed circumstance only in criminal proceedings; therefore it cannot become the basis for the revision of a decision in civil proceedings.

Granting the Constitutional Court authority to consider and adjudicate upon the constitutionality of the decisions of the common courts is associated with lots of positive factors.

As it is known, According to the European Convention on Human Rights European Court can only deal with the matter after all domestic remedies exhausted $^{18}$, what means that the case should be considered by all of the court instances. In case of Georgia, the court of last resort is the Supreme Court of Georgia. If the Constitutional Court gains new authority, for the purposes of convention, it will be considered as a court of last resort, as it is e.g. in the case of Germany. In this way the number of applications against Georgia will significantly reduce.

According to the organic law "on Constitutional Court of Georgia" consideration of a constitutional claim or constitutional submission should not exceed nine months from the registration of the constitutional claim, however it does not determine the time-limit for adopting the final decision. In a result sometimes adoption of a final decision can take two years. In spite of that fact, protection and restoration of violated rights will be more effective through Constitutional Court rather than through European Court of Human Rights, where due to a large number of applications sometimes one case can last more than five years. In addition to this, proceedings before the European Court of Human Rights are related to sufficient financial resources (defender costs, expenses to attend the proceedings).

New authority of the Constitutional Court may become more effective human rights protection mechanism. Decisions of the Constitutional Court of Georgia do not have retroactive force. However, if the Constitutional Court will be given the authority to examine constitutionality of the decisions of common courts and will conclude that the decision violates basic human rights and freedoms, it should become the ground to return the case to the common court for the revision. In this way the person will be actually able to restore violated right. If the European Court of Human Rights founds that the right guaranteed by the convention has been violated, it obliges

${ }^{18}$ European Convention on human rights, Article 1. 
the respondent state to pay the fixed amount of money to the party for non-pecuniary damages or to cover other expenses. Final rulings of the European Court of Human Rights can also become newly revealed circumstances both in criminal and in civil proceedings, but in this case recovery of the right is also associated with the protracted period of time.

Disadvantages that can be caused by granting the Constitutional Court the new authority are that Constitutional Court will interfere with the common courts' competence, especially with the competence of Supreme Court of Georgia, which is the court of last resort. However, regarding the fact that the person can only apply to the Supreme Court when the specific requirements of the law are met, in some cases Court of Appeals can become the court of last resort.

According to the fact that after granting Constitutional Court the new authority, number of the constitutional claims will be increased, a new, third board should be formed responsible for considering and adjudicating upon the constitutionality of the decisions of common courts.

In conclusion, taking into consideration all the aforementioned, the initiative of the Public Defender should be positively evaluated. In case of its realization new guarantees for the protection of human rights will be created.

\section{BIBLIOGR APHY}

Demetrashvili A., Constitutional Law Manual, Tbilisi 2005, p. 335.

Eremadze K., The balancing of interests in a democratic society, Tbilisi 2013.

Izoria L., Korkelia K., Kublashvili K., Khubua G., Comments on the Georgian Constitution. Fundamental Human Rights and Freedoms. Meridiani publishing house, Tbilisi 2005, pp. 334-336.

Khetsuriani J., The Authority of the Constitutional Court of Georgia, Issues of the Constitutionality of referendum and Elections, "Constitutional Law Review" 2009, no. 1. Khetsuriani J., The Georgian Constitutional Court 's Power in the Protection of Fundamental Human Rights, "Constitutional Law Review" 2011, no. 4.

Melkadze O., Some Aspects Regarding the Constitutionality of the Organic Law of Georgia on the Constitutional Court, "Journal Georgian Law Review", $10^{\text {th }}$ edition, 2001, p. 59.

Tugushi T., Burjanadze G., Mshvenieradze G., Gotsiridze G. and Menabde V., Human Rights and Case-Law of the Constitutional Court of Georgia, Tbilisi, 2013, p. 608. 